\title{
Relationship between dimensions of grandiose narcissism and Facebook addiction among university students
}

\author{
Julia M. Balcerowska (D) ${ }^{A, B, C, D, E, F}$, Adriana Biernatowska ${ }^{B, C, D, E, F}$, Paulina Golińska (D) ${ }^{D, E, F}$, \\ Julia Barańska $a^{D, E}$ \\ University of Gdansk, Gdansk, Poland
}

\section{BACKGROUND}

The present study aimed to examine the relationship between different dimensions of grandiose narcissism and Facebook addiction among undergraduate students. In the Polish population, grandiose narcissism has been shown to have a four-factor structure: Self-sufficiency, Vanity, Leadership and Admiration demand. Studies consistently show that grandiose narcissism is related to Facebook addiction. However, it is still not clear which dimensions of grandiose narcissism are particularly related to this addiction.

\section{PARTICIPANTS AND PROCEDURE}

The sample consisted of 486 students (313 women, 173 men). The mean age in the sample was $M=21.56(S D=4.50)$. Students were invited to participate anonymously in the study during lectures or classes. Part of the sample completed the questionnaire featured on Facebook. Valid and reliable psychometric tools were applied to assess grandiose narcissism, the Big Five personality traits and Facebook addiction.
RESULTS

The results showed that Facebook addiction was positively related to Admiration demand and negatively related to Self-sufficiency after controlling for age, gender, and the Big Five personality traits. However, there was no relationship between Vanity or Leadership and Facebook addiction above and beyond other study variables.

\section{CONCLUSIONS}

The results showed that a particular dimension of grandiose narcissism (i.e. passive and dependent on others) could be viewed as a risk factor of Facebook addiction. On the other hand, the active and independent dimension of grandiose narcissism could be viewed as a protective factor in the context of Facebook addiction.

\section{KEY WORDS}

Facebook addiction; SNS addiction; narcissism; grandiose narcissism; personality

CORRESPONDING AUTHOR - Julia M. Balcerowska, Faculty of Social Sciences, Institute of Psychology, University of Gdansk, 4 Bażyńskiego Str., 80-309 Gdansk, Poland, e-mail: julia.balcerowska@phdstud.ug.edu.pl AUthors' CONTRIBUtion - A: Study design - B: Data collection - C: Statistical analysis - D: Data interpretation .

E: Manuscript preparation $\cdot$ F: Literature search $\cdot$ G: Funds collection

To CITE THIS ARTICLE - Balcerowska, J. M., Biernatowska, A., Golińska, P., \& Barańska, J. (2019). Relationship between dimensions of grandiose narcissism and Facebook addiction among university students. Current Issues in Personality Psychology, 7(4), 313-323.

RECEIVED 23.07.2019 • REVIEWED 30.10.2019 • ACCEPTED 12.12.2019 • PUBLISHED 30.12.2019 


\section{BACKGROUND}

It is estimated that in 2021 there will be approximately 3.02 billion users of social networking sites (SNSs) globally (Statistica, 2020). In the third quarter of 2019, Facebook had an average of 1.62 billion daily active users (Facebook, 2020). With the increasing popularity of SNSs such as Facebook, problems involving excessive use and potential negative consequences of this phenomenon have emerged. Previous empirical findings suggest that excessive or addictive use of SNSs could impair psychological and social well-being of an individual and their next of kin (Andreassen, 2015; Frost \& Rickwood, 2017; Hussain \& Griffiths, 2018).

According to uses and gratifications theory, the use of a particular medium is goal-directed and could be related to different forms of gratification as well as distinct needs underlying this use (Katz, Haas, \& Gurevitch, 1973). Within the SNS users, there are various motivations of usage (Chen, 2011; Mull \& Lee, 2014; Sheldon \& Bryant, 2016; Throuvala, Griffiths, Rennoldson, \& Kuss, 2019). According to Nadkarni and Hoffman (2012) using Facebook is determined by two motives: a need for self-presentation and a need for affiliation. What is more, studies show that relationship maintenance is the main reason for Facebook use (Kuss \& Griffiths, 2011). Therefore, it is crucial to differentiate results from respective sites (e.g. Facebook), in order to understand which specific gratifications underlie the use of a particular SNS (Ryan, Chester, Reece, \& Xenos, 2014).

Devolution from normal to problematic use of SNSs occurs when online social networking is perceived by the person as an essential mechanism to relieve stress, depression, and loneliness (Xu \& Tan, 2012). Problematic SNS use has been conceptually defined as a disorder that does not involve ingestion of a psychoactive substance and shares qualities related to a behavioral addiction (Griffiths, 2005; Kuss \& Griffiths, 2017). Other researchers have used the term SNS addiction and defined it as "being concerned about SNSs all the time, driven by a strong motivation to $\log$ on to or use SNSs, and to devote so much time and effort to SNSs that it impairs other social activities, studies/job, interpersonal relationships, and/or psychological health and well-being" (Andreassen \& Pallesen, 2014, p. 4054). This definition could also refer to Facebook addiction as an example of SNS addiction (Atroszko et al., 2018).

Theoretical models of SNS addiction have emphasized the prominence of predisposing factors (i.e. personality) in the context of development and maintenance of this addiction (Andreassen, 2015; Andreassen et al., 2013; Atroszko et al., 2018; Balcerowska \& Biernatowska, 2018; Brand, Young, Laier, Wölfling, \& Potenza, 2016). Studies are often based on the Big Five model of personality emphasizing the following main dimensions: neuroticism, extra- version, openness to experience, agreeableness, and conscientiousness (Wiggins, 1996). With reference to the Big Five, a meta-analysis showed that Facebook addiction was positively related to neuroticism and negatively to conscientiousness. What is more, there are weak negative relationships between extraversion, agreeableness, and openness to experience, on the one hand, and Facebook addiction, on the other (Marino, Gini, Vieno, \& Spada, 2018).

In the context of SNS usage, the facilitating role of narcissism has been recognized in theory and supported by research findings (Barry \& McDougall, 2018). People who scored higher on narcissism attached greater importance to Facebook, were more active on Facebook, and spent more time using it (Błachnio, Przepiórka, \& Rudnicka, 2016). Facebook could be a place that promotes narcissistic tendencies by encouraging users to present themselves frequently and in the most positive ways (Gnambs \& Appel, 2017). Studies conducted by Błachnio, Przepiórka, and Rudnicka (2016) showed that narcissism is a positive predictor of personal importance, instrumental Facebook use, social Facebook use, and Facebook intensity. Moreover, narcissists spend more time on SNSs, have a larger circle of contacts and they are particularly inclined to upload more photos compared to non-narcissists (Gnambs \& Appel, 2017).

There are at least two different dimensions of narcissism (i.e., grandiose vs. vulnerable) that have been discussed using a variety of titles (e.g., Dickinson \& Pincus, 2003; Miller \& Campbell, 2008; Wink, 1991). The first one is characterized by grandiosity, self-importance, dominance, and uniqueness, while the second is related to interpersonal hypersensitivity, insecurity, and social withdrawal (Dickinson \& Pincus, 2003; Miller et al., 2011). Studies consistently show that grandiose narcissism, as a personality trait, is a heterogeneous construct, with different, often contradictory, effects of its aspects (e.g. Ackerman et al., 2011; Back et al., 2013; Emmons, 1984; Raskin \& Terry, 1988). On the basis of Emmons's model (1984), Polish researchers proposed a four-factor structure of grandiose narcissism including (1) Self-sufficiency, which involves confidence in one's abilities, (2) Vanity, which refers to the delight of self, (3) Leadership, connected with the conviction about one's impact on others as well as manipulation, and (4) Admiration demand, which reflects a desire to be admired and involves the sense of entitlement. Furthermore, Bazińska and Drat-Ruszczak (2000) proposed two second-order dimensions: (1) active-passive, related to engaging in action vs. being passive (Leadership and Self-sufficiency vs. Admiration demand and Vanity), and (2) dependence-independence from others in which the main regulator of self-esteem is self vs. the main self-regulatory strategy is comparing oneself to others (Vanity and Self-sufficiency vs. Leadership and Admiration demand). 
In the presented model, all factors are related to self-esteem but two active dimensions (Leadership and Self-sufficiency) show stronger relations to selfesteem than passive ones (Admiration demand and Vanity). What is more, only Self-sufficiency is positively related to actual well-being, while Vanity and Admiration demand are positively related to anticipated well-being (i.e., an expectation of a high level of life satisfaction in the future). Furthermore, the only factor that is negatively related to neuroticism is Selfsufficiency (Bazińska \& Drat-Ruszczak, 2000). Accordingly, every dimension of grandiose narcissism involves a different pattern of self-esteem regulation: for some narcissists, other people are necessary for their self-regulation, while other narcissists are selfsufficient. What is more, the associations are also differentiated in relation to the active-passive dimension, which results in diverse effects on well-being. Thus, for some narcissists, using Facebook might be highly gratifying, while for others, this type of activity might be neutral or even aversive. Therefore, different dimensions of grandiose narcissism might differ in the way they are related to Facebook addiction.

Studies constantly show that narcissism is positively related to SNS addiction (e.g. Andreassen, Pallesen, \& Griffiths, 2017; Kircaburun, Demetrovics, \& Tosuntaş, 2018). Furthermore, previous research confirmed that grandiose narcissists are at a higher risk of developing Facebook addiction (Atroszko et al., 2018; Błachnio \& Przepiórka, 2018). However, previous investigations did not explain which dimensions of grandiose narcissism are particularly related to this addiction. Firstly, the nature of the relationship between Vanity and Facebook addiction, or between Leadership and Facebook addiction, is not clear. Secondly, the mechanism linking narcissism and Facebook addiction had been predominantly based on exhibitionistic narcissistic needs, desire to be admired, and self-promotion strategies on SNSs (Gnambs \& Appel, 2017). Using Facebook might be highly gratifying especially for those narcissists that are passive and depend on others. In line with this, the strategy to confirm one's self-esteem through self-promotion and exhibitionistic tendencies could lead narcissists demanding admiration to Facebook addiction. Thirdly, those aspects of grandiose narcissism related to confidence, assertiveness, emotional stability, and independence from others could be viewed as protective factors in the context of developing and maintaining disorders (Bazińska \& Drat-Ruszczak, 2000). Therefore, self-sufficient narcissists might be less prone to Facebook addiction. Last but not least, previous studies showed that Facebook addicts have problems with emotional regulation, are rather neurotic, and unconscientious (Marino et al., 2018). On the other hand, they are extravert and crave social interactions, especially self-validation through those interactions (Atroszko et al., 2018). In line with this multidimensional personality portrait of Facebook addicts, it is crucial to investigate the relative contribution of particular personality traits (i.e. the Big Five personality traits and narcissism) to this addiction.

Taking into account that personality traits are crucial risk factors in developing Facebook addiction (Andreassen et al., 2013; Brand et al., 2016), the aim of this study is to examine the relationship between this addiction and different dimensions of grandiose narcissism. Therefore, this research aimed to differentiate the effects of grandiose narcissism composites on Facebook addiction above and beyond demographic variables, and the Big Five personality traits. On the basis of previous research and theoretical frameworks, we hypothesize that: Admiration demand is positively related to Facebook addiction (H1); Selfsufficiency is negatively related to Facebook addiction (H2). What is more, we posed the following research questions: Is there a relationship between Leadership and Facebook addiction? (Q1); Is there a relationship between Vanity and Facebook addiction? (Q2).

\section{PARTICIPANTS AND PROCEDURE}

\section{PARTICIPANTS}

Initially, the sample comprised 580 people. Before the analyses, data were screened and two participants who did not have accounts on any SNSs were excluded. Due to missing data on relevant variables, 94 participants were further eliminated from the analyses. Finally, 486 respondents were found in the sample: 313 women (64.4\%) and 173 men (35.6\%). The mean age was $M=21.56(S D=4.50)$. According to declarative data, respondents used Facebook on average 2.81 hours $(S D=2.51)$ a day and have had a Facebook account for 5.32 years $(S D=1.63)$.

\section{MEASURES}

Facebook addiction. The Bergen Facebook Addiction Scale (BFAS; Andreassen, Torsheim, Brunborg, $\&$ Pallesen, 2012) includes six items that are based on the addiction components model (Griffiths, 2005). Responses are provided on a 5-point Likert scale ranging from 1 (very rarely) to 5 (very often). The higher scores indicate greater Facebook addiction. The Polish version of the BFAS has shown good validity and reliability in previous studies (Atroszko et al., 2018; Charzyńska \& Góźdź, 2014). In the present sample, the Cronbach's $\alpha$ reliability coefficient was .81 .

Grandiose narcissism. The Narcissistic Personality Inventory (NPI; Bazińska \& Drat-Ruszczak, 2000) was used to assess the grandiose narcissism. The inventory measures four factors of grandiose narcissism: Leadership (11 items), Vanity (5 items), Self-sufficiency 
(7 items), and Admiration Demand (11 items). Respondents provided answers on a five-point Likert scale, from 1 (it's not me) to 5 (it's me). It showed adequate validity and reliability, as well as good psychometric properties in previous studies (Bazińska \& Drat-Ruszczak, 2000). In this study, Cronbach's $\alpha$ coefficients were .88 for Leadership, .74 for Vanity, .76 for Self-sufficiency and .88 for Admiration Demand.

Personality. The Polish version (Atroszko, 2015) of the Ten Item Personality Inventory (TIPI; Gosling, Rentfrow, \& Swann, 2003) was used to assess the Big Five model of personality: Extraversion, Agreeableness, Conscientiousness, Emotional stability, and Openness to experience. Respondents provided answers on a 7-point Likert scale, ranging from 1 (disagree strongly) to 7 (agree strongly). The TIPI has shown good validity and reliability in previous studies (Atroszko, 2015; Atroszko, Andreassen, Griffiths, \& Pallesen, 2016a, 2016b; Atroszko et al., 2018). In the presented sample, the Spearman-Brown reliability coefficient was .66 for Extraversion, .43 for Agreeableness, .67 for Conscientiousness, .68 for Neuroticism and .30 for Openness to experience. The TIPI demonstrates good validity and biased estimates of reliability using internal consistency measures, which should be expected due to the small number (just two) of items per dimension (Gosling et al., 2003). Therefore, less biased measures of reliability should be used, such as the test-retest reliability, which for the original scale yielded acceptable correlations between repeated measurements within a 6-week interval, varying from .62 for Openness to .77 for Extraversion (Gosling et al., 2003).

\section{PROCEDURE}

Data collection used convenience sampling. Students were invited to participate anonymously in the study during lectures or classes; all of them agreed to do so. The estimated response rate was above $95 \%$. Part of the sample (38.9\%) collection was conducted via a questionnaire placed on Facebook. Respondents were asked to follow a hyperlink to access the survey. The response rate for online surveys is impossible to determine (Fan \& Yan, 2010). Before starting to respond, the participants received detailed information about the study. Data collection took place from January 2016 to April 2016. Participation in the study was anonymous and no monetary or other material rewards were offered.

\section{STATISTICAL ANALYSIS}

Means, standard deviations and correlation coefficients between study variables were calculated. Multiple hierarchical regression analysis was conducted in which Facebook addiction was the dependent variable. This model allowed us to analyze whether dimensions of grandiose narcissism are significant predictors of Facebook addiction after controlling for demographic variables and the Big Five personality traits. Additionally, multiple hierarchical regression was used in order to investigate which particular dimension of grandiose narcissism is the more appropriate predictor for the dependent variable (i.e. Facebook addiction). In the first step, gender and age were entered. Independent variables entered in the second step were the Big Five personality traits (Neuroticism, Extraversion, Openness to experience, Agreeableness, Conscientiousness). In the third step, four dimensions of narcissism were entered. Additionally, the lower and upper 95\% confidence intervals were calculated to compare the beta weights. All tests were two-tailed and the significance level was set to $\alpha=.05$. Preliminary analyses showed that the regression assumptions about normality, linearity, homoscedasticity and multicollinearity $\left(\mathrm{VIF}_{\max }=2.59\right)$ were met. Standardized regression coefficients were reported. All statistical analyses were conducted in IBM SPSS 25.

\section{ETHICS}

The study was carried out in accordance with the Declaration of Helsinki. All gathered data were anonymous, and participants were informed of all the relevant details about the study and their role in it, including the ability to leave the study at any point. Obtaining formal and written informed consent was not regarded as necessary as voluntary completion of the questionnaires was regarded as providing consent, the study was anonymous and no medical information was gathered.

\section{RESULTS}

Mean scores, standard deviations, percentages and correlation coefficients of the study variables are presented in Table 1. Correlation analysis showed some significant relationships between Facebook addiction and studied variables. Facebook addiction was negatively associated with male gender $(r=-.23, p<.001)$, Conscientiousness $(r=-.13, p<.001)$ and Self-sufficiency $(r=-.11, p=.020)$. Positive correlations with Facebook addiction have been reported with Neuroticism $(r=.18, p<.001)$, Admiration demand $(r=.31$, $p<.001)$ and Vanity $(r=.17, p<.001)$.

The regression analysis showed that the independent variables added in step 1 explained 5.8\% of variance of Facebook addiction $(F(2,483)=14.74$, $p<.001)$. Gender $(\beta=-.24, p<.001)$ and age $(\beta=-.07$, $p=.048)$ had significant effects on Facebook addiction in step 1. Independent variables added in step 2 
Julia M. Balcerowska, Adriana Biernatowska, Paulina Golińska, Julia Barańska

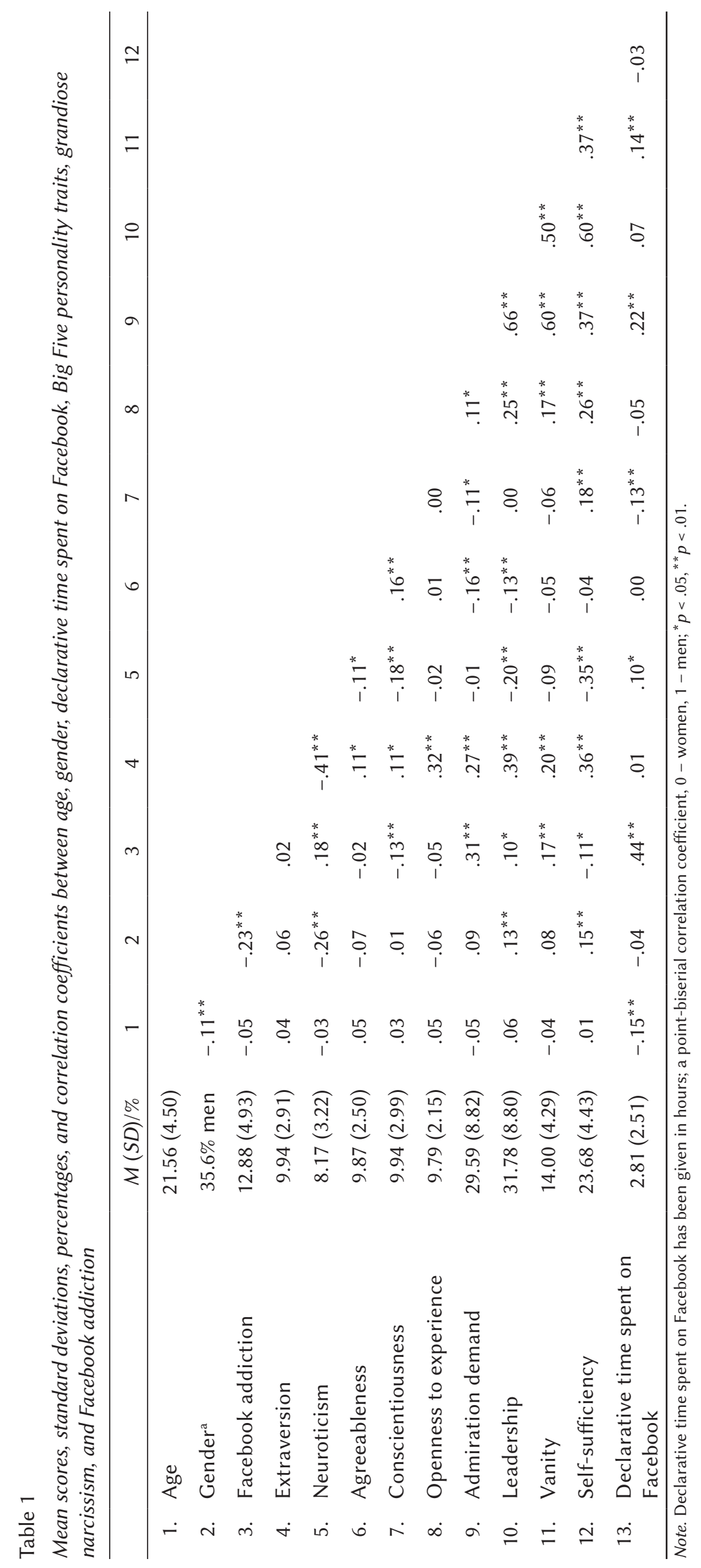


explained additional $4.4 \%$ of variance $(F(5,478)=4.64$, $p<.001)$. Gender $(\beta=-.21, p<.001)$, Extraversion $(\beta=.15, p=.004)$, Conscientiousness $(\beta=-.11$, $p=.013)$, Neuroticism $(\beta=.16, p=.002)$ and Openness to experience $(\beta=-.10, p=.025)$ showed significant effects on Facebook addiction in Step 2. Independent variables added in step 3 explained an additional $11.5 \%$ of variance $(F(4,474)=17.42 p<.001)$. After adding the dimensions of narcissism to the regression model in step 3, the effects of the Big Five personality traits ceased to be significant. Gender $(\beta=-.23$, $p<.001)$, Admiration demand $(\beta=.37, p<.001)$, and Self-sufficiency $(\beta=-.18, p=.001)$ showed significant effects on Facebook addiction in Step 3. In total, the model explained $21.6 \%$ of Facebook addiction's variance (gender, Admiration demand, Self-sufficiency; $F(11,474)=11.90, p<.001)($ see Table 2$)$.

\section{DISCUSSION}

The aim of the study was to investigate the relationships between different dimensions of grandiose narcissism and Facebook addiction among university students. To the best of the authors' knowledge, there are no studies examining the relative contribution of different aspects of grandiose narcissism to Facebook addiction above and beyond age, gender and Big Five personality traits.

There was a negative relationship between age and Facebook addiction before including the Big Five personality traits in the tested model, which is congruent with previous studies (e.g. Andreassen et al., 2016; Błachnio, Przepiórka, \& Pantic, 2015). SNSs might meet young people's needs, especially those related to establishing and maintaining relationships

Table 2

Results of hierarchical multiple regression analyses in which age, gender, Big Five personality traits and grandiose narcissism were regressed upon results of Facebook addiction (standardized regression coefficients, lower and upper $95 \%$ confidence intervals are reported)

\begin{tabular}{|c|c|c|c|c|c|}
\hline \multirow[t]{2}{*}{ Step } & \multirow[t]{2}{*}{ Predictor } & \multicolumn{4}{|c|}{ Facebook addiction } \\
\hline & & $\beta$ & $\mathrm{LCl}$ & $\mathrm{UCl}$ & $\Delta R^{2}$ \\
\hline \multirow[t]{2}{*}{1} & Age & $-.07^{*}$ & -.15 & .01 & $.06^{* *}$ \\
\hline & Gender ${ }^{\mathrm{a}}$ & $-.24^{* *}$ & -.33 & -.15 & \\
\hline \multirow[t]{7}{*}{2} & Age & -.06 & -.13 & .02 & $.04^{* *}$ \\
\hline & Gender ${ }^{\mathrm{a}}$ & $-.21^{* *}$ & -.31 & -.12 & \\
\hline & Extraversion & $.15^{*}$ & .05 & .26 & \\
\hline & Agreeableness & -.01 & -.11 & .09 & \\
\hline & Conscientiousness & $-.11^{*}$ & -.20 & -.03 & \\
\hline & Neuroticism & $.16^{* *}$ & .06 & .26 & \\
\hline & Openness to experience & $-.10^{*}$ & -.21 & .00 & \\
\hline \multirow[t]{12}{*}{3} & Age & -.05 & -.11 & .03 & $.12^{* *}$ \\
\hline & Gender ${ }^{\mathrm{a}}$ & $-.23^{* *}$ & -.32 & -.14 & \\
\hline & Extraversion & .05 & -.05 & .17 & \\
\hline & Agreeableness & .03 & -.08 & .12 & \\
\hline & Conscientiousness & -.05 & -.14 & .04 & \\
\hline & Neuroticism & .07 & -.03 & .17 & \\
\hline & Openness to experience & -.08 & -.18 & .01 & \\
\hline & Admiration demand & $.37^{* *}$ & .24 & .50 & \\
\hline & Leadership & -.02 & -.14 & .11 & \\
\hline & Vanity & .05 & -.05 & .15 & \\
\hline & Self-sufficiency & $-.18^{* *}$ & -.29 & -.07 & \\
\hline & Total $R^{2}$ & & & & $.22^{* *}$ \\
\hline
\end{tabular}

Note. ${ }^{\mathrm{a}} 0$ - women, $1-\mathrm{men} ;{ }^{*} p<.05,{ }^{*} p<.01$. 
with others (Riva, Wiederhold, \& Cipresso, 2016). Therefore, using Facebook could be highly gratifying, or even addictive, for young people (Andreassen et al., 2016).

Furthermore, there was a positive relationship between Facebook addiction and female gender, even after controlling for all the investigated variables in the tested model (i.e. age, the Big Five personality traits and dimensions of the grandiose narcissism). This suggests that being female might be an independent risk factor for Facebook addiction. The results are consistent with previous studies indicating that women are at higher risk of developing Facebook addiction than men (Andreassen et al., 2012; Atroszko et al., 2018).

The prominence of personality as a risk factor in development and maintenance of SNS addiction has been emphasized in theoretical models and previous investigations (e.g. Andreassen, 2015; Andreassen et al., 2013; Brand et al., 2016). With reference to the above-mentioned models, there were positive relationships between neuroticism, extraversion, and Facebook addiction, as well as negative relationships between openness to experience, conscientiousness, and Facebook addiction, before including grandiose narcissism dimensions in the tested model. This result is congruent with a previous meta-analysis on problematic Facebook use and personality (Marino et al., 2018). Nonetheless, after controlling for grandiose narcissism dimensions there was no relationship between Facebook addiction and the Big Five personality traits. This is in line with the hypothesis that SNS use might function as an opportunity to display grandiosity (Barry \& McDougall, 2018). Moreover, narcissistic individuals receive self-enhancing positive feedback from other users, which could be a strong gratification for them (McCain \& Campbell, 2018). Accordingly, even if the Big Five personality traits play a significant role in the context of Facebook addiction, there might be more crucial and specific personality risk factors which are more accurate referring to the specific personality portrait of Facebook addicts.

In the context of the unique contribution of particular dimensions of grandiose narcissism, the results showed that Admiration demand has an effect on Facebook addiction over and above age, gender, and the Big Five personality traits. Admiration demand reflects the need to be a prominent person, who is noticeable, admired by others and famous (Bazińska \& Drat-Ruszczak, 2000). What is more, demanding admiration is related to the sense of entitlement, so when narcissistic needs are not fulfilled, one can fall into narcissistic rage related to aggressive and hostile responses of narcissists when facing an ego-threatening situation (Bushman \& Baumeister, 1998; Twenge \& Campbell, 2003). Grandiose narcissists seek approval from the external environment, which may in turn lead to difficulties in emotional regulation (Given-Wilson, Mcllwain, \& Warburton, 2011). What is more, narcissistic individuals experience greater anger and anxiety, as well as lower self-esteem, after receiving negative feedback about their performance (Morf \& Rhodewalt, 2001). Thus, although grandiose narcissists report themselves as free of psychological distress, they engage in deliberate acts to protect this appearance and have difficulties in regulating self-esteem and emotions in this process (Akinci, 2015). Regulating self-esteem by using Facebook could provide strong gratification for narcissists, who need others to confirm their self-worth. Furthermore, Facebook is a place that provides an opportunity to strictly control one's own image by adding only positive and self-promoting information (Barry, Doucette, Loflin, Rivera-Hudson, \& Herrington, 2015). Thus, it is presumed that positive feedback from other users decreases stress and improves mood by enhancing self-esteem. In line with this, expressing ambitions and displaying success to a potentially large audience may be a strong gratification for narcissists demanding admiration (Andreassen et al., 2017).

There was no relationship between Leadership and Facebook addiction. Leadership refers to a belief that one has high abilities to control other people and have an influence on them (Bazińska \& DratRuszczak, 2000). According to the results, narcissists dependent on others will use Facebook features as a tool for self-regulation only by the creation of an environment where they can be admired, and not by having an impact on other users, who serve merely as an audience (Andreassen et al., 2017). In the proposed structure of grandiose narcissism, Leadership contains a belief of influencing others, while Admiration demand is related to the assumption that admiration from others does not have to be contingent on one's own merits (Bazińska \& Drat-Ruszczak, 2000). In line with this, Leadership could be viewed as a personality predictor of high and intensive Facebook use (e.g. influencers), but not Facebook addiction.

Self-sufficiency has an effect on Facebook addiction over and above age, gender, and the Big Five personality traits. It might be explained by the fact that self-sufficient narcissists regulate their self-esteem by self, rather than other people. Thus, these narcissists do not need other people to preserve their high self-esteem (Bazińska \& Drat-Ruszczak, 2000). Therefore, social reinforcement that they might receive on Facebook is not as gratifying for them as for other narcissists (Biernatowska, Balcerowska, \& Pianka, 2017). Additionally, because Self-sufficiency is defined as beliefs in one's individualism, independence, high competencies, and success, being dependent on others' approval is opposite to the narcissist's own image. Narcissistic self-sufficiency is related to well- 
being which is also correlated with lower susceptibility to addictions (Caplan, 2002). Accordingly, the results suggest that the higher level of Self-sufficiency, the lower probability of Facebook addiction.

In the investigated model, Vanity was not uniquely Facebook addiction. Vanity is a dimension of grandiose narcissism that is passive and independent from others. Furthermore, this dimension is characterized by self-admiration (Bazińska \& Drat-Ruszczak, 2000). Therefore, there is no need for other people's appreciation to regulate self-esteem and mood for these narcissists. A previous study showed that using Facebook is related to maintaining social interactions and companionship (Kuss \& Griffiths, 2011); hence vain narcissists who do not need social reinforcement do not engage in excessive Facebook use.

The present study significantly adds to the existing literature on Facebook addiction and provides valuable insights into the nature of the risk and protective factors of this addiction. In terms of limitations, all data were self-reported and cross-sectional design was used, rendering the data vulnerable to limitations associated with such data (e.g., common method, social desirability and recall biases). The sample was not representative of the general population of Facebook users and comprised students, which puts restrictions on the generalizability to other populations.

Future studies should further investigate the nature of the relationship between Facebook addiction and grandiose narcissism. Further studies should also examine the regulating role of self-esteem in the relationship between particular dimensions of grandiose narcissism and SNS addiction. Moreover, cross-cultural studies, as well as studies based on the diverse theories of grandiose narcissism, should be conducted. Future research should also attempt to collect and analyze data on demographic variables, especially gender, along with specific SNS usage patterns and SNS addiction. Last but not least, the potential role of motives of using SNSs in the context of different dimensions of grandiose narcissism should be further studied.

\section{CONCLUSIONS}

The present study suggests that in the context of Facebook addiction grandiose narcissism is an important factor that could lead to Facebook addiction. Moreover, grandiose narcissism as a personality trait seems to be a stronger predictor of Facebook addiction than the Big Five personality traits. In conclusion, this study shows that it is not general narcissism itself that is related to Facebook addiction, but it probably is the particular dimension of grandiose narcissism (passive and dependent on others). On the other hand, Self-sufficiency as the most indepen- dent aspect of grandiose narcissism related to strong belief about one's self-efficacy is negatively related to Facebook addiction. This result suggests that this particular dimension of grandiose narcissism functions as a protective factor in the context of Facebook addiction. The results of the study may be helpful in designing prevention programs which might concentrate on strengthening the self-sufficiency in the group of individuals susceptible to Facebook addiction. Furthermore, narcissism should be taken into account in addiction therapy programs, despite the fact that not all aspects of this trait might contribute to Facebook addiction.

\section{ACKNOWLEDGEMENTS}

The authors would like to thank Artur Sawicki for his valuable comments on a draft of this paper.

\section{RefERENCES}

Ackerman, R. A., Witt, E. A., Donnellan, M. B., Trześniewski, K. H., Robins, R. W., \& Kashy, D. A. (2011). What does the narcissistic personality inventory really measure? Assessment, 18, 67-87. https://doi.org/10.1177/1073191110382845

Akınci, i. (2015). The relationship between the types of narcissism and psychological well-being: the roles of emotions and difficulties in emotion regulation (Unpublished master's thesis). Middle East Technical University, Ankara.

Andreassen, C. S. (2015). Online social network site addiction: a comprehensive review. Current Addiction Reports, 2, 175-184. https://doi.org/10.1007/ s40429-015-0056-9

Andreassen, C. S., Billieux, J., Griffiths, M. D., Kuss, D. J., Demetrovics, Z., Mazzoni, E., \& Pallesen, S. (2016). The relationship between addictive use of social media and video games and symptoms of psychiatric disorders: a large-scale cross-sectional study. Psychology of Addictive Behaviors, 30, 252-262. https://doi.org/10.1037/adb0000160

Andreassen, C. S., Griffiths, M. D., Gjertsen, S. R., Krossbakken, E., Kvam, S., \& Pallesen, S. (2013). The relationships between behavioral addictions and the five-factor model of personality. Journal of Behavioral Addictions, 2, 90-99. https://doi. org/10.1556/JBA.2.2013.003

Andreassen, C. S., \& Pallesen, S. (2014). Social network site addiction - an overview. Current Pharmaceutical Design, 20, 4053-4061. https://doi.org/ $10.2174 / 13816128113199990616$

Andreassen, C. S., Pallesen, S., \& Griffiths, M. D. (2017). The relationship between addictive use of social media, narcissism, and self-esteem: Findings from a large national survey. Addictive 
Behaviors, 64, 287-293. https://doi.org/10.1016/j. addbeh.2016.03.006

Andreassen, C. S., Torsheim, T., Brunborg, G. S., \& Pallesen, S. (2012). Development of a Facebook addiction scale. Psychological Reports, 110, 501-517. https://doi.org/10.2466/02.09.18.PR0.110.2.501-517

Atroszko, P. A. (2015). The structure of study addiction: Selected risk factors and the relationship with stress, stress coping and psychosocial functioning (Unpublished doctoral dissertation). University of Gdansk, Gdansk.

Atroszko, P. A., Andreassen, C. S., Griffiths, M. D., \& Pallesen, S. (2016a). Study addiction: a crosscultural longitudinal study examining temporal stability and predictors of its changes. Journal of Behavioral Addictions, 5, 357-362. https://doi. org/10.1556/2006.5.2016.024

Atroszko, P. A., Andreassen, C. S., Griffiths, M. D., \& Pallesen, S. (2016b). The relationship between study addiction and work addiction: a cross-cultural longitudinal study. Journal of Behavioral Addictions, 5, 708-714. https://doi.org/10.1556/2006.5.2016.076

Atroszko, P. A., Balcerowska, J. M., Bereznowski, P., Biernatowska, A., Pallesen, S., \& Andreassen, C. S. (2018). Facebook addiction among Polish undergraduate students: Validity of measurement and relationship with personality and well-being. Computers in Human Behavior, 85, 329-338. https:// doi.org/doi:10.1016/j.chb.2018.04.001

Back, M. D., Kufner, A. C. P., Dufner, M., Gerlach, T. M., Rauthmann, J. F., \& Denissen, J. J. A. (2013). Narcissistic admiration and rivalry: Disentangling the bright and dark sides of narcissism. Journal of Personality and Social Psychology, 105, 1013-1037. https://doi.org/10.1037/a0034431

Balcerowska, J. M., \& Biernatowska, A. (2018). Uzależnienia behawioralne - przegląd badań obejmujących osobowościowe i psychospołeczne korelaty uzależnień [Behavioral addiction: a review of the personality and psychosocial correlates]. In W. Ślusarczyk, R. Wilczyńska, \& G. Frischke (Eds.), Natogi. Medyczne i kulturowe aspekty uzależnień na przestrzeni dziejów [Addictions. Medical and cultural aspects of addictions throughout history] (pp. 117-131). Lublin: Wydawnictwo Uniwersytetu Marii Curie-Skłodowskiej.

Barry, C. T., Doucette, H., Loflin, D. C., Rivera-Hudson, N., \& Herrington, L. L. (2015). "Let me take a selfie": Associations between self-photography, narcissism, and self-esteem. Psychology of Popular Media Culture, 6, 48-60. https://doi.org/10.1037/ ppm0000089

Barry, C. T., \& McDougall, K. H. (2018). Social media: Platform or catalyst for narcissism? In A. Hermann, A. Brunell, \& J. Foster (Eds.), Handbook of trait narcissism (pp. 435-441). Cham: Springer.

Bazińska, R., \& Drat-Ruszczak, K. (2000). Struktura narcyzmu w polskiej adaptacji kwestionariusza
NPI Ruskina i Halla [Structure of narcissism in the Polish adaptation of the Narcissistic Personality Inventory]. Czasopismo Psychologiczne, 6, 171-188. Biernatowska, A., Balcerowska, J. M., \& Pianka, L. (2017). Why narcissists are using Facebook? The relationship between narcissism dependent on others and using Facebook among students. In J. Leśny \& J. Nyćkowiak (Eds.), Badania i rozwój młodych naukowców w Polsce - Spoteczeństwo: psychologia i socjologia [Research and development of the young scientists in Poland - Society: psychology and sociology] (pp. 8-15). Poznań: Młodzi Naukowcy.

Błachnio, A., \& Przepiórka, A. (2018). Facebook intrusion, fear of missing out, narcissism, and life satisfaction: a cross-sectional study. Psychiatry Research, 259, 514-519. https://doi.org/10.1016/j. psychres.2017.11.012

Błachnio, A., Przepiórka, A., \& Pantic, I. (2015). Internet use, Facebook intrusion, and depression: Results of a cross-sectional study. European Psychiatry, 30, 681-684. https://doi.org/10.1016/j.eurpsy. 2015.04.002

Błachnio, A., Przepiórka, A., \& Rudnicka, P. (2016). Narcissism and self-esteem as predictors of dimensions of Facebook use. Personality and Individual Differences, 90, 296-301. https://doi.org/10.1016/j. paid.2015.11.018

Brand, M., Young, K. S., Laier, C., Wölfling, K., \& Potenza, M. N. (2016). Integrating psychological and neurobiological considerations regarding the development and maintenance of specific Internetuse disorders: an interaction of Person-AffectCognition-Execution (I-PACE) model. Neuroscience \& Biobehavioral Reviews, 71, 252-266. https://doi. org/10.1016/j.neubiorev.2016.08.033

Bushman, B. J., \& Baumeister, R. F. (1998). Threatened egotism, narcissism, self-esteem, and direct and displaced aggression: Does self-love or self-hate lead to violence? Journal of Personality and Social Psychology, 75, 219-229. https://doi. org/10.1037/0022-3514.75.1.219

Caplan, S. E. (2002). Problematic Internet use and psychosocial well-being: development of a theorybased cognitive-behavioral measurement instrument. Computers in Human Behavior, 18, 553-575. https://doi.org/10.1016/S0747-5632(02)00004-3

Charzyńska, E., \& Góźdź, J. (2014). W sieci uzależnienia. Polska adaptacja Skali Uzależnienia od Facebooka (the Bergen Facebook Addiction Scale) C. S. Andreassen, T. Torsheima, G. S. Brunborga i S. Pallesena [In the network of addiction. Polish adaptation of Facebook addiction scale (the Bergen Facebook Addiction Scale) by C. S. Andreassen, T. Torsheim, G. S. Brunborg, and S. Pallesen]. Chowanna, 1, 163-185.

Chen, G. M. (2011). Tweet this: a uses and gratifications perspective on how active Twitter use 
gratifies a need to connect with others. Computers in Human Behavior, 27, 755-762. https://doi. org/10.1016/j.chb.2010.10.023

Dickinson, K. A., \& Pincus, A. L. (2003). Interpersonal analysis of grandiose and vulnerable narcissism. Journal of Personality Disorders, 17, 188-207. https://doi.org/10.1521/pedi.17.3.188.22146

Emmons, R. A. (1984). Factor analysis and construct validity of the narcissistic personality inventory. Journal of Personality Assessment, 48, 291-300. https://doi.org/10.1207/s15327752jpa4803_11

Facebook (2020, January, 4). Facebook reports third quarter 2019 results. Retrieved from https://investor.fb.com/investor-news/press-release-details/2019/Facebook-Reports-Third-Quarter-2019Results/default.aspx

Fan, W., \& Yan, Z. (2010). Factors affecting response rates of the web survey: a systematic review. Computers in Human Behavior, 26, 132-139. https://doi. org/10.1016/j.chb.2009.10.015

Frost, R. L., \& Rickwood, D. J. (2017). A systematic review of the mental health outcomes associated with Facebook use. Computers in Human Behavior, 76, 576-600. https://doi.org/10.1016/j.chb.2017.08.001

Given-Wilson, Z., Mcllwain, D., \& Warburton, W. (2011). Meta-cognitive and interpersonal difficulties in overt and covert narcissism. Personality and Individual Differences, 50, 1000-1005. https://doi. org/10.1016/j.paid.2011.01.014

Gnambs, T., \& Appel, M. (2017). Narcissism and social networking behavior: a meta-analysis. Journal of Personality, 86, 200-212. https://doi.org/10.1111/ jopy. 12305

Gosling, S. D., Rentfrow, P. J., \& Swann, W. B., Jr. (2003). A very brief measure of the Big-Five personality domains. Journal of Research in Personality, 379, 504528. https://doi.org/10.1016/S0092-6566(03)00046-1

Griffiths, M. (2005). A "components" model of addiction within a biopsychosocial framework. Journal of Substance Use, 10, 191-197. https://doi.org/ 10.1080/14659890500114359

Hussain, Z., \& Griffiths, M. D. (2018). Problematic social networking site use and comorbid psychiatric disorders: a systematic review of recent large-scale studies. Frontiers in Psychiatry, 9, 686. https://doi. org/10.3389/fpsyt.2018.00686

Katz, E., Haas, H., \& Gurevitch, M. (1973). On the use of the mass media for important things. American Sociological Review, 38, 164-181. https://doi. org/10.2307/2094393

Kircaburun, K., Demetrovics, Z., \& Tosuntaş, Ş. B. (2018). Analyzing the links between problematic social media use, dark triad traits, and self-esteem. International Journal of Mental Health and Addiction, 17, 1496-1507. https://doi.org/10.1007/ s11469-018-9900-1

Kuss, D. J., \& Griffiths, M. D. (2011). Online social networking and addiction - a review of the psy- chological literature. International Journal of Environmental Research and Public Health, 8, 35283552. https://doi.org/10.3390/ijerph8093528

Kuss, D. J., \& Griffiths, M. D. (2017). Social networking sites and addiction: Ten lessons learned. International Journal of Environmental Research and Public Health, 14, 1-17. https://doi.org/10.3390/ ijerph 14030311

Marino, C., Gini, G., Vieno, A., \& Spada, M. M. (2018). A comprehensive meta-analysis on problematic Facebook use. Computers in Human Behavior, 83, 262-277. https://doi.org/10.1016/j.chb.2018.02.009

McCain, J. L., \& Campbell, W. K. (2018). Narcissism and social media use: a meta-analytic review. Psychology of Popular Media Culture, 7, 308-327. https://doi.org/10.1037/ppm0000137

Miller, J. D., \& Campbell, W. K. (2008). Comparing clinical and social-personality conceptualizations of narcissism. Journal of Personality, 76, 449-476. https://doi.org/10.1111/j.1467-6494.2008.00492.x

Miller, J. D., Hoffman, B. J., Gaughan, E. T., Gentile, B., Maples, J., \& Keith Campbell, W. (2011). Grandiose and vulnerable narcissism: a nomological network analysis. Journal of Personality, 79, 1013-1042. https://doi.org/10.1111/j.1467-6494.2010.00711.x

Morf, C. C., \& Rhodewalt, F. (2001). Unraveling the paradoxes of narcissism: a dynamic self-regulatory processing model. Psychological Inquiry, 12, 177196. https://doi.org/10.1207/S15327965PLI1204_1

Mull, I. R., \& Lee, S. E. (2014). "PIN" pointing the motivational dimensions behind Pinterest. Computers in Human Behavior, 33, 192-200. https://doi. org/10.1016/j.chb.2014.01.011

Nadkarni, A., \& Hoffman, S. G. (2012). Why do people use Facebook? Personality and Individual Differences, 52, 243-249. https://doi.org/10.1016/j. paid.2011.11.007

Raskin, R., \& Terry, H. (1988). A principal-components analysis of the Narcissistic Personality Inventory and further evidence of its construct validity. Journal of Personality and Social Psychology, 54, 890902. https://doi.org/10.1037/0022-3514.54.5.890

Riva, G., Wiederhold, B. K., \& Cipresso, P. (2016). Psychology of social media: From technology to identity. In G. Riva, B. K. Wiederhold, \& P. Cipresso (Eds.), The psychology of social networking: Personal experience in online communities (pp. 1-11). Warszawa: De Gruyter Open.

Ryan, T., Chester, A., Reece, J., \& Xenos, S. (2014). The uses and abuses of Facebook: a review of Facebook addiction. Journal of Behavioral Addictions, 3, 133-148. https://doi.org/10.1556/JBA.3.2014.016

Sheldon, P., \& Bryant, K. (2016). Instagram: Motives for its use and relationship to narcissism and contextual age. Computers in Human Behavior, 58, 89-97. https://doi.org/10.1016/j.chb.2015.12.059

Statistica (2020, January, 4). Number of social network users worldwide from 2010 to 2021. Retrieved from 
https://www.statista.com/statistics/278414/number-of-worldwide-social-network-users/

Throuvala, M. A., Griffiths, M. D., Rennoldson, M., \& Kuss, D. J. (2019). Motivational processes and dysfunctional mechanisms of social media use among adolescents: a qualitative focus group study. Computers in Human Behavior, 93, 164-175. https://doi.org/10.1016/j.chb.2018.12.012

Twenge, J. M., \& Campbell, W. K. (2003). "Isn't it fun to get the respect that we're going to deserve?" Narcissism, social rejection, and aggression. Personality and Social Psychology Bulletin, 29, 261272. https://doi.org/10.1177/0146167202239051

Wiggins, J. S. (1996). The five-factor model of personality: Theoretical perspectives. New York, NY: Guilford Press.

Wink, P. (1991). Two faces of narcissism. Journal of Personality and Social Psychology, 61, 590-597. https://doi.org/10.1037/0022-3514.61.4.590

Xu, H., \& Tan, B. C. (2012). Why do I keep checking Facebook: Effects of message characteristics on the formation of social network services addiction. Retrieved from http://aisel.aisnet.org/icis2012/proceedings/ResearchInProgress/31/ 